\title{
TWENTY YEARS OF AIRLINE DEREGULATION: THE IMPACT ON OUTLYING SMALL COMMUNITIES
}

\author{
J. Richard Jones \\ 'Trinity University
}

Many rural communities over the years have had to endure reduced levels of scheduled transportation services to the point that some have indeed experienced a cessation of services. Accompanying the deregulation of airlines in 1978 was the expressed fear that transportation services would continue to spiral downward and various communities would lose their population bases. This study investigates the two decades of airline deregulation and the impact that that 1978 legislation has had on small communities that are situated 100 air miles or more from any hub airport. Chief among the findings are: (1) that service levels have indeed deteriorated as indicated by the fact that over one-quarter of the non hubs lost all service, (2) of those locations that retained some service, nearly two-thirds experienced reduced levels of service, and (3) the overall pattern of population growth remained approximately the same whether service was eliminated, reduced, or increased.

\section{INTRODUCTION}

Transportation has long been an area of interest for economists, geographers, logisticians, marketers, sociologists and other students of economic and social development. Indeed, from very early on in the development of this country (as well as others for that matter), transportation has facilitated the movement necessary for some geographical points to flourish as production centers and distribution centers. In addition to sustaining individual consumers who now make their livelihood in those locations, the transportation lifeline connects approximately $20 \%$ of the Nation's consumers who live in locations that are depicted as rural. While the urbanization of America has been inexorably proceeding from $5 \%$ in 1790 to $25 \%$ just after the Civil War to $64 \%$ following WWII to $75 \%$ in 1990 , the information "revolution" is providing the impetus to alter this trend. The question that arises is, can the transportation system meet the needs of these changing times?

Over the decades there have been few who have argued that the U.S. transportation system is not the best in the world. While it is still true that the U.S. system is without equal on an overall basis, there are fears that the quality and quantity of transportation to and from this country's rural areas is on a general decline. Rural transportation, as true with other aspects of rural life, must be considered part of a broad policy base. Numerous policy measures have 
been proposed to alleviate the pressures on our urban areas; measures involving jobs creation, energy availability, etc. Although certain measures have been suggested to improve our rural transportation system as well, it appears nonetheless that our transport alternatives may be reducing the attractiveness of those towns and villages situated substantial distances from cities. On the one hand, while obtaining goods may be more expensive in outlying areas, this is clearly an economic trade-off made by those living there. On the other hand however, public transportation alternatives to and from small towns are becoming more scarce almost regardless of one's ability to pay.

\section{PURPOSE}

The purpose of this study is to investigate the impact that airline deregulation has had on small communities in the U.S. in the 20 years that the industry has had economic freedom. While the passage of the Airline Deregulation Act of 1978 (PL 95-204) on October 24, 1978 may be best remembered for the removal of pricing, entry and exit restrictions as they applied to the major domestic trunklines (now major carriers) such as American, Delta and United, the same statute created a need for commuter airline service (now referred to as regional airlines). The question addressed here is how well the small communities are being served twenty years after the fact. Inasmuch as "the national transportation policy statement, a preamble to the Airline Deregulation Act of 1978 , specifically calls for a comprehensive and convenient system of continuous scheduled airline service for small communities and isolated areas," (Davis and Dillard 1982) one would expect service in 1998 to be rather like that of 1978 .

\section{BACKGROUND}

Many scholars consider the transportation and rural community equation to be of crisis proportion. Reich (1987, p.38) envisions this country becoming a bicoastal economy and "if rural America is to be revived, rural transportation will have to become more accessible and efficient." The difficulties associated with rural life and transportation upheavals are well documented (Kihl 1988, Schwab 1987). In a most descriptive fashion, Shultz (1987) envisions (as an outgrowth of deregulation) "an increasing number of small communities undoubtedly will shrivel like corn in a drought."

Airline deregulation as it has involved small communities has attracted the attention of many researchers. Several have focused on the federal subsidy aspect that Congress built into the 1978 deregulation legislation which was supposed to allow communities a decade (but still continues) to prepare for the possible impact of deregulation (Cunningham and Eckard 1987, Vellenga and Vellenga 1986, Addus 1985 and 1984, J.R. Meyer 1981). Others have suggested that state and local governments play a prominent role in providing air service to small communities (Williamson, Cunningham and Singer 1982). While interest concerning deregulation and its impact on small communities has lagged behind that focusing upon the implications regarding major cities and major carriers, some works have been put forth (Jones and Cocke 1985, Stephenson and Beier 1981).

\section{PUBLIC TRANSPORTATION DEMISE}

A transportation system is generally inclusive of several modes: rail, motor (auto, truck, and bus), air, water, and pipeline. Insofar as passenger travel is concerned, there are fewer options and the number of those options is becoming smaller. Only the private automobile continues as a viable option for many individuals who live in small outlying communities. Notwithstanding the ubiquitous automobile, in some instances weather makes this a difficult option. Moreover, for certain individuals, their age, medical condition and/or the total cost of operating an auto preclude this option. 
From the standpoint of movement to and from small communities, rail service has become in the last few decades nearly nonexistent, while water transportation has hardly ever been an option for most communities. Bus service, while often viewed as the backbone for rural common carrier service, is rapidly being curtailed. As one news magazine states "For many Americans who live in small towns, when there's no Greyhound, there's no exit" i.e., from the community (Gallagher 1990). The thought that "there is always the Greyhound bus"..that will "take you to obscure places you call home and away from places you never want to see again... when you've got no car, when the airfare is too high (or there's no airport at all), when the railroad tracks have long gone to weed" (Gallagher 1990) rings somewhat hollow these days. Greyhound, while serving 9,500 communities in 1990 (Gallagher 1990), is providing service to only 2,600 destinations today (Greyhound 1998).

Air transportation at one time certainly was considered the answer to overcoming major distances associated with life in smaller communities. With the deregulation of the airline industry, that vision has been altered significantly as more and more small communities face the difficulties of reduced service or worse yet an abandonment of service. The U.S. Department of Transportation contends that General Aviation (GA) aircraft also provide access to intercity (or town) movement via the many thousands of airfields where scheduled service is now available. DOT's figures show the number of airports growing from 6,881 to 18,224 during the period from 1960 to 1995 . Further, if one possessed the resources to own and maintain a general aviation aircraft, only 667 of those airports are FAA certificated and but 446 of those airports have FAA or FAA contracted towers (U.S. DOT, 1997). Consequently, while marketers are fond of referencing the ever mobile consumer, it is difficult to maintain that general aviation is the answer to the small community transportation problem.

\section{AIRPORT CLASSIFICATION SYSTEM}

Over the years the Federal Aviation Administration (FAA) has developed a system of classifying airports predicated on the volume of passenger activity at each location in relation to the total of domestic passenger activity. In summary; that system is as follows:

Large Hubs: Enplane 1.00\% or more of the Nation's passengers. Examples are Chicago, San Francisco and Washington D.C.

Medium Hubs: Enplane $.250 \%$ to $.999 \%$ of the Nation's passengers. Examples are Buffalo, Indianapolis and Salt Lake City.

Small Hubs: Enplane .05\% to $.249 \%$ of the Nation's passengers. Examples are Colorado Springs, Knoxville, and Shreveport.

Non-Hubs: Enplane fewer than $.05 \%$ of the Nation's passengers. Examples are Bozeman, MT, Macon, GA, and Williamsport, PA.

According to the U. S. Department of Transportation, in 1995, there were 29 large hubs (67 airports), 33 medium hubs (59 airports), 58 small hubs (73 airports) and 561 non hubs (593 airports). (U.S. DO'T 1997)

Given the definitions cited above, it is rather understandable that most, if not all, airports serving smaller communities will fall into the non-hub airport category. It should be noted however, that not all of the cities and towns served by a non hub airport are necessarily sparsely populated. Indeed, non hub designations include many in the size category of places such as Glasgow, MT (population 3,656) and Hancock, MI (population 4,565) while many others reflect the size of Pocatello, ID (population 51,344 ) and Huntington, WV (population 53,941). 


\section{RESEARCH DESIGN}

In October 1978, the FAA data indicated that there were 503 non-hub airports in the 48 contiguous states and commercial service was provided at 485 non-hubs or $96.4 \%$ of the total(CAB 1981). One of the recurring themes heard throughout the debate regarding the wisdom of deregulating the Nation's airlines centered upon the service that would be extended small outlying cities and towns. Opponents of deregulation early on warned that the result would be "less service ... particularly on the lowdensity routes serving small communities" (J.R. Meyer et al. 1981). Indeed, this prophecy seems to have been borne out in the score of years since deregulation was implemented. As of January 1, 1998, after allowing for the 20 new non hubs that have begun to receive service since 1978 , only 320 non-hub airports were receiving scheduled commercial air service.(RAA 1998)

Obviously some non-hub airports are located relatively short distances from large, medium or small hub airports. Therefore as the result of their proximity to a hub airport, some locations have experienced relatively little dislocation since the discontinuation of service occurred. For example, Benton Harbor, Michigan is 20 air miles (and 30 road miles) from South Bend Indiana (a small hub airport), and 70 air miles (and 91 road miles) to Chicago (a large hub airport). Nonetheless, there are other non-hub airports that are located a days drive from any hub airport. Butte, Montana, for example, is 192 air miles (224 road miles) from Billings, MT (the nearest small hub airport), 266 air miles (318 road miles) from Spokane, (the nearest medium hub airport) and 477 air miles (600 road miles) from Seattle (the nearest large hub airport). Unquestionably, the further a small community is located from any hub airport, the greater the hardship if service is eliminated and, in some instances, even a reduction in service can have a negative impact. Consequently, this study is designed to investigate the impact airline deregulation has had on small communities that are located at least 100 air miles from any hub airport. This is unmistakably a conservative measure of distance since road (or driving) distances can be considerably further. For example, North Bend, OR is 71 air miles from the closest hub airport, Eugene, OR (a small hub) but is 105 road miles from that community:

Of the 485 non hubs listed by the FAA as having scheduled commercial airline service in 1978, 110 non hubs are located at least 100 air miles from the nearest hub of any size. On October 1, 1998, approximately 20 years following the passage of the Deregulation Act, according to the Official Airline Guide twenty-nine (or 26.4\%) of those 110 small communities are not receiving any scheduled airline service

Thus, from the above figures it can be deduced that 81 of the "original" 110 non hubs have retained some level of service since 1978. In fact some locations have shown gains in service levels, at least from the standpoint of seats available at the specific location. Other cities and towns have not been as fortunate, however, inasmuch as they have experienced a reduction in service levels although not to the extreme of having scheduled service eliminated.

To determine the shifts in non hub service, the number of airline seats available per week was employed. While the number of flights into a non hub could have been used, that figure conceals the fact that various aircraft are configured quite differently insofar as seating capacity is concerned. For example, the Beech 1900I) (Raytheon Aircraft) seats 19, the Embraer 120 Brasilia seats 30 , the Saab 340 seats 35 , the Canadian Regional Jet Series 200 (Bombardier Aerospace) seats 50 and the Boeing 737-300 series has the capacity for 128 passengers.

Service thus is defined as seats available per week and not the quality of that service. While many officers of various chambers of commerce 
and governmental officials have testified that their locale does not receive jet service or as frequent service as they desire, the fact remains that they do receive service and for this study that is what was assessed (U.S. Senate 1996). Furthermore, while some research has centered on factors such as seating comfort, noise levels, food and beverage service, etc. they were also not evaluated in this study (Jones and Cocke 1981, Davis and Dillard 1982).

\section{FINIDINGS}

The base year data (1978) for the 81 non hubs that have experienced continued service since deregulation originated with the Civil Aeronautics Board (1981). Following the "sunset" of the CAB and the data that it generated, comparable present-day data are not readily available; so for this study they were computed using flight data published in the Official Airline Guide(OAG). The data were developed by selecting all flights listed in the $\mathrm{OAG}$ that arrived at each non hub (one assumes that each seat in turn departed that location as well) and determining the number of seats per flight and ultimately compiling those numbers into the measure of "seats per week" at each location. This process requires, as noted previously, that the configuration for each aircraft be determined as well as any airline configuration differences that exist from airline to airline. The comparison of the number of seats per week available at each non hub located at least 100 nautical miles from any hub airport for the years 1978 and 1998 is shown in Table 1.

It is fairly obvious from the data depicted in Table 1 that, on an overall basis, deregulation has not been particularly kind to outlying small communities. Indeed, of those small communities that experienced continuous air service since 1978 and are at least 100 nautical miles from any hub airport, $60.5 \%$ (49 of 81 ) are experiencing a lower level of service (i.e., seats available) now as compared to just prior to deregulation (as of
October 1, 1978). In the aggregate, the 81 small communities lost $9.42 \%$ of the capacity that they had in October 1978. Some locations, contrary to the overall slippage in service levels, experienced major increases e.g., Mountain Home AR 729.09\%, Grand Rapids MN 386.11\%, Jackson Hole Wr 292.67\% and Brownwood TX 151.47\%. As the data show however, several of the locations that had major improvements did so with a rather small numerical base in 1978. Still there are numerous cities and towns that have had to confront major disruptions in service, e.g., Iron Mountain MI -86.84\%, Cape Girardeau MO $82.91 \%$, Alamosa CO $-79.37 \%$, Laramie WY $78.75 \%$ and Twin Falls ID $-75.36 \%$.

TABLE 1

\section{Changes In Service to Small Communities 1978 vs. 1998}

\begin{tabular}{lrrr}
\hline & \multicolumn{3}{c}{ Available Service } \\
Community & 1978 & 1998 & Change \\
\hline Aberdeen SD & 3,740 & 1,972 & $-47.27 \%$ \\
Abilene TX & 3,285 & 1,925 & -41.40 \\
Alamosa CO & 1,750 & 361 & -79.37 \\
Alliance NE & 532 & 722 & +35.71 \\
Bozeman MT & 5,090 & 7,529 & +47.92 \\
Brownwood TX & 136 & 342 & +151.47 \\
Cape Girardeau MO & 2,112 & 361 & -82.91 \\
Carlsbad NM & 960 & 323 & -66.25 \\
Casper WY & 4,546 & 2,030 & -55.35 \\
Cedar City UT & 707 & 570 & -19.38 \\
Clarksburg WV & 2,239 & 1,235 & -44.84 \\
Cortez CO & 1,050 & 380 & -63.81 \\
Crescent City CA & 560 & 630 & +12.50 \\
Devil's Lake ND & 672 & 361 & -46.28 \\
Dodge City KS & 850 & 627 & -26.24 \\
Duluth MN & 11,094 & 10,919 & -1.58 \\
Durango CO & 4,482 & 2,891 & -35.50 \\
Elko NV & 1,512 & 2,250 & +48.81
\end{tabular}




\begin{tabular}{|c|c|c|c|c|c|c|c|}
\hline Eureka/Arcata CA & 3,868 & 3,687 & -4.67 & Miles City MT & 228 & 456 & +100.00 \\
\hline Farmington NM & 3,280 & 2,280 & -30.49 & Missoula MT & 5,769 & 8,287 & +43.65 \\
\hline Flagstaff $A Z$ & 1,226 & 1,317 & +7.42 & Mountain Home AR & 55 & 456 & +729.09 \\
\hline Ft Leonard Wood MO & 2,481 & 342 & -86.22 & New Bern NC & 3,074 & 1,850 & -39.82 \\
\hline Gallup NM & 1,400 & 361 & -74.21 & North Platte NE & 2,350 & 760 & -67.66 \\
\hline Garden City KS & 799 & 893 & +11.76 & Pasco WA & $\tau, 004$ & 9,672 & +38.09 \\
\hline Gillette WY & 1,782 & 840 & -52.87 & Pellston MI & 2,206 & 2,170 & -1.63 \\
\hline Glasgow, MT & 456 & 228 & -50.00 & Pendleton OR & 1,739 & 999 & -42.55 \\
\hline Glendive $\mathrm{MT}$ & 228 & 342 & +50.00 & Pierre SD & 2,396 & 2,344 & -2.07 \\
\hline Goodland KS & 442 & 684 & +54.75 & Pocatello ID & 1,813 & 2,049 & +13.02 \\
\hline Grand Canyon $\mathrm{AZ}$ & 3,848 & 6,314 & +64.09 & Presque Isle ME & 2,548 & 760 & -70.17 \\
\hline Grand Rapids MN & 180 & 875 & +386.11 & Redding CA & 2,432 & 2,420 & -0.49 \\
\hline Great Falls MT & 10,410 & 10,137 & -2.63 & Riverton WY & 1,379 & 779 & -43.51 \\
\hline Hancock MI & 1,946 & 1,645 & -15.47 & Rock Springs WY & 1,750 & 475 & -72.86 \\
\hline Harrison AR & 1,400 & 456 & -67.43 & Roswell NM & 875 & 836 & -4.46 \\
\hline Harve MT & 129 & 228 & +76.74 & St George UT & 617 & 1,260 & +104.21 \\
\hline Hays KS & 816 & 836 & +2.45 & Sault St Marie MI & 672 & 735 & +9.38 \\
\hline Helena MT & 2,314 & 4,905 & +111.97 & Scottsbluff NE & 2,700 & 855 & -68.33 \\
\hline Hibbing MN & 3,066 & 1,358 & -55.71 & Sidney MT & 228 & 323 & +41.67 \\
\hline Huntington WV & 7,525 & 2,952 & -60.77 & Silver City NM & 936 & 209 & -77.63 \\
\hline Idaho Falls ID & 1,974 & 3,559 & +80.29 & Springfield MO & 13,822 & 15,686 & +13.49 \\
\hline Int'l Falls MN & 0 & 910 & + & Steamboat Springs Co & 2,464 & 630 & -74.43 \\
\hline Iron Mountain MI & 4,620 & 608 & -86.84 & Twin Falls II) & 4,261 & 1,050 & -75.36 \\
\hline Jackson Hole WY & 1,050 & 4,123 & +292.67 & Walla Walla WA & 2,796 & 999 & -64.27 \\
\hline Jacksonville NC & 4,215 & 2,229 & -47.12 & Williston ND & 570 & 399 & -30.00 \\
\hline Kalispell MT & 3,884 & 4,099 & +5.54 & Wolf Point MT & 228 & 361 & +58.33 \\
\hline Key West FL & 2,674 & 6,537 & +44.47 & Yuma AZ & 2,008 & 1,230 & -38.75 \\
\hline
\end{tabular}

$\begin{array}{lrrr}\text { Kirksville MO } & 270 & 312 & +15.56 \\ \text { Klamath Falls OR } & 2,722 & 962 & -64.66 \\ \text { Lake Havasu City AZ } & 814 & 475 & -41.65 \\ \text { Lamar CO } & 442 & 684 & +54.75 \\ \text { Laramie WY } & 1,699 & 361 & -78.75 \\ \text { Laredo TX } & 2,406 & 2,035 & -15.42 \\ \text { Liberal KS } & 1,000 & 361 & -63.90 \\ \text { Marquette MI } & 2,310 & 2,463 & +6.62 \\ \text { Me Cook NE } & 1,165 & 722 & -38.03\end{array}$

At the outset of any study that focuses on the well-being of a community, it must be acknowledged that many variables can account for that community's growth or decline. One factor that is often cited as vital to the welfare of a city or town is transportation. Surely if one listens to the officials of communities that are about to lose part or all of their scheduled transportation service, whether rail, bus or air; one could only surmise that the community in 
question undoubtedly will decline if not fade away completely. In fact, the arguments given for continued service are not too dissimilar to those large cities that contend that a major league professional sports franchise will "make or break" that city.

While it is obvious that more detailed research is needed to adequately measure all the variables (geographical, economic and social) and their contributions to a community's growth or decline, it is interesting nonetheless to compare the population figures of the 81 communities that maintained some level of service with the 29 communities that had their service eliminated during the period involved in this study (19781998). Table 2 presents the population figures (1980 to 1996) for those communities that lost their scheduled air service. From the data provided in Table 2 it is difficult to fully accept the argument that with the service so goes the community since 21 (or $72.4 \%$ ) of the cities and towns gained in population during the period. Again it must be emphasized that a number of factors may be at play here (e.g., retirement locations, gambling ).

In regard to the corresponding population figures for those communities that had ongoing operations throughout the two decades, the growth pattern shown in Table 3 is nearly identical to those locations that completely lost their service. During the time period involved in this study, of those locales that had continuous service, 57 of the 81 (or $71.3 \%$ ) cities or towns experienced population growth while 23 (or $28.7 \%$ ) suffered a decline in population (one non hub serves a military installation and population figures are not generally available).
TABLE 2

Population Changes of Communities That Lost Commercial Air Service - 1980 To 1996

\begin{tabular}{|c|c|c|c|}
\hline Community & 1980 & 1996 & $\begin{array}{l}\text { Percent } \\
\text { Change }\end{array}$ \\
\hline Austin NV & 370 & 405 & $+9.46 \%$ \\
\hline Baker OR & 9,471 & 9,693 & +2.34 \\
\hline Battle Mountain NV & 2,749 & 4,296 & +56.28 \\
\hline Bowman ND & 2,071 & $1,60^{\circ}$ & -22.65 \\
\hline Columbus IN & 30,614 & 32,963 & +7.67 \\
\hline Craig CO & 9,239 & 8,504 & -7.96 \\
\hline Eagle Pass TX & 21,407 & 27,554 & +28.71 \\
\hline Ely NV & 4,882 & 4,978 & +1.97 \\
\hline Enterprise A. & 18,033 & 21,253 & +17.86 \\
\hline Eureka NV & 650 & 1,577 & +142.62 \\
\hline Fillmore LT & 2,083 & 1,988 & -4.56 \\
\hline Frenchville ME & 1,450 & 1,169 & -19.38 \\
\hline Hermiston OR & 9,642 & 11,160 & +15.74 \\
\hline Inyokern CA & 800 & $900^{\mathrm{a}}$ & +12.75 \\
\hline La Grande OR & 11,793 & 12,228 & +3.69 \\
\hline Lake of Ozarks MO & 534 & 701 & +31.27 \\
\hline Mackinac Island MI & 479 & 455 & -5.01 \\
\hline Milford UT & 1,293 & 1,241 & -4.02 \\
\hline Osage Beach MO & 1,992 & 3,163 & +58.79 \\
\hline Rawlins WY & 11,547 & 8,947 & -22.58 \\
\hline Richfield UT & 5,482 & 6,057 & +10.49 \\
\hline Richland WA & 33,578 & 37,445 & +11.52 \\
\hline Sidney NB & 6,010 & 6,128 & +1.96 \\
\hline Sterling CO & 11,385 & 10,535 & -7.47 \\
\hline Tonopah NV & 1,952 & $3,616^{\mathrm{a}}$ & +85.25 \\
\hline Trinidad CO & 9,663 & 8,831 & +8.61 \\
\hline Wells CO & 1,218 & 1,479 & +21.43 \\
\hline Winnemuca NV & 4,140 & 8,004 & +93.33 \\
\hline Winslow AZ & 7,921 & 10,420 & +31.55 \\
\hline
\end{tabular}

a population figure is for the year 1990 
TABLE 3

Changes in Population of Small Communities

1980 Vs. 1996

\begin{tabular}{|c|c|c|c|}
\hline Community & $\begin{array}{c}1980 \\
\text { Population }\end{array}$ & $\begin{array}{c}1996 \\
\text { Population }\end{array}$ & $\begin{array}{l}\text { Percent } \\
\text { Change }\end{array}$ \\
\hline Aberdeen SD & 29,956 & 25,088 & $-16.25 \%$ \\
\hline Abilene TX & 98,315 & 108,476 & +10.34 \\
\hline Alamosa CO & 6,830 & 7,739 & +13.31 \\
\hline Alliance NE & 9,869 & 9,702 & -2.69 \\
\hline Bozeman MT & 21,645 & 28,522 & +31.77 \\
\hline Brownwood TX & 19,396 & 19,255 & -0.83 \\
\hline Cape Girardeau MC & 1034,361 & 35,464 & +3.21 \\
\hline Carlsbad NM & 25,496 & 26,535 & +4.08 \\
\hline Casper WY & 51,016 & 48,800 & -4.34 \\
\hline Cedar City UT & 10,972 & 17,811 & +62.33 \\
\hline Clarksburg WV & 22,371 & 17,410 & -22.28 \\
\hline Cortez CO & 7,095 & 8,781 & +23.76 \\
\hline Crescent City CA & 3,075 & 6,866 & +123.28 \\
\hline Devil's Lake ND & 7,442 & 7,672 & +3.09 \\
\hline Dodge City KS & 18,001 & 22,430 & +24.60 \\
\hline Duluth MN & 92,811 & 83,699 & -9.82 \\
\hline Durango CO & 11,426 & 13,923 & +21.85 \\
\hline Elko NV & 8,758 & 19,371 & +121.18 \\
\hline Eureka/Arcata CA & 36,491 & 42,463 & +16.37 \\
\hline Farmington NM & 31,222 & 37,936 & +21.50 \\
\hline Flagstaff AZ & 34,743 & 55,094 & +58.58 \\
\hline Ft Leonard Wood $\mathrm{V}$ & MO $n / a$ & $n / a$ & $\mathrm{n} / \mathrm{a}$ \\
\hline Gallup NM & 18,161 & 20,591 & +13.38 \\
\hline Garden City KS & 18,256 & 25,366 & +38.95 \\
\hline Gillette WY & 12,134 & 19,202 & +58.28 \\
\hline Glasgow, MT & 4,455 & 3,656 & -17.93 \\
\hline Glendive MT & 5,978 & 4,557 & -23.77 \\
\hline Goodland KS & 5,708 & 4,834 & -15.31 \\
\hline Grand Canyon AZ & 1,348 & $1,499^{\mathrm{a}}$ & +11.20 \\
\hline Grand Rapids MN & 7,934 & 8,162 & +2.87 \\
\hline Great Falls MT & 56,725 & 57,758 & +1.81 \\
\hline
\end{tabular}

Harrison AR

5,122

9,567

Harve MT

Hays KS

Helena MT

Hibbing MN

Huntington $\mathrm{WV}$

10,891

16,301

23,938

21,193

63,684

Idaho Falls ID

39,590

Int'] Falls MN'

8,417

Iron Mountain MI

8,341

Jackson Hole WY

4,571

Jacksonville $\mathrm{NC}$

17,056

Kalispell M'T

10,648

Key West FL。

24,382

Kirksville MO

17,167

Klamath Falls (OR

I a amar CO

16,661

7,713

Lake Havasu

$$
\text { City AZ }
$$

Laramie WY

Laredo TX

Liberal KS

Marquette MI

Mc Cook NE

Miles City MT

Missoula MT

Mountain Home AR 8,066

New Bern NC

14,557

North Platte NE

24,479

Pasco WA

17,944

Pellston MI

565

Pendeton OR

14,521

Pierre SD

11,973

Pocatello ID

46,340

Presque Isle ME

11,172

Redding $\mathrm{CA}$

41,955

$\begin{array}{rr}4,565 & -10.87 \\ 11,537 & +20.59 \\ 10,232 & -6.05 \\ 17,911 & +9.88 \\ 27,982 & +16.89 \\ 17,600 & -16.95 \\ 53,941 & -6.71 \\ 48,079 & +21.44 \\ 8,000 & -4.95 \\ 8,530 & +2.27 \\ 5,614 & +22.82 \\ 69,889 & +309.76 \\ 15,678 & +47.24 \\ 25,339 & +3.93 \\ 17,107 & -0.35 \\ 18,580 & +11.52 \\ 8,473 & +9.85\end{array}$

39,503

164,899
26,583

17,551

17,016

7,926

8,882

51,204

11,236

21,464

23,369

23,910

597

15,8933

13,422

51,344

9,213

$+148.31$

$+8.90$

$+80.32$

$+17.71$

$-26.93$

$-5.69$

$-7.50$

$+53.36$

$+39.30$

$+47.45$

$-4.53$

$+33.25$

$+5.66$

$+9.45$

$+12.10$

$+10.80$

$-17.53$

$76.616+82.61$ 


\begin{tabular}{|c|c|c|c|}
\hline Riverton WX' & 9,588 & 10,050 & +4.82 \\
\hline Rock Springs WY & 19,458 & $19,74^{\circ} 2$ & +1.46 \\
\hline Roswell N.II & 39,676 & 47,559 & +19.87 \\
\hline St George LT & 11,350 & 42,763 & +276.77 \\
\hline Sault St Marie MI & 14,448 & 15,300 & +5.910 \\
\hline Scottsbluff NE & 14,156 & 14,400 & +1.72 \\
\hline Sidney MT & 5,726 & 4,971 & -13.19 \\
\hline Silver City N.M & 9,887 & 12,007 & +21.44 \\
\hline Springtield MO & 133,116 & 143,407 & +7.73 \\
\hline $\begin{array}{l}\text { Steamboat } \\
\text { Springs Co }\end{array}$ & 5,098 & 6,768 & +32.76 \\
\hline Twin Falls ID & 26,209 & 31,989 & +22.05 \\
\hline Walla Walla WA & 25.618 & 28,529 & +11.36 \\
\hline Williston NI) & 13,336 & 12,718 & -4.63 \\
\hline Wolf Point . M'T & 3,074 & 2,874 & -6.51 \\
\hline Yuma $A \%$ & 42,433 & 60,519 & $+42.6 \%$ \\
\hline
\end{tabular}

\section{SLMMARY AND CONCLUSIONS}

In the 200 plus years of this country's history, small communities, situated well away from population centers that attract a major share of transportation activity, have struggled to maintain their economic and social viability in the face of declining public transportation options. In most instances, those communities have not enjoyed the economic benefit of being located advantageously on a major river, highway or railroad. Nevertheless most have survived as the result of some other advantages among which could be good soil, a steady, honest albeit small workforce, and lower taxes and crime rates. Over time all modes of transportation have found varying degrees of diseconomies associated with serving these outlying areas. In the end, many carriers in all modes of transportation have found it necessary to reduce or eliminate service to these small communities.

Undoubtedly, marketers and consumers located in those outlying towns and cities as well as those attempting to reach the rural customer have experienced considerable anxiety. Twenty years ago the Airline Deregulation Act granted the Nation's airlines the freedom to serve communities based upon profitability standards without the onerous cross-subsidy quid pro quo that required service to the contrary. Most assuredly there are and have been subsidies that have allowed the continuation of service notwithstanding economic losses. Section 419, Essential Air Service Subsidy Payments for 1997 totaled more than $\$ 40$ million, covering 70 locations in the 48 contiguous states with the average subsidy to maintain service to those cities and towns amounting to $\$ 572,067$ annually (R-t 1998, Jones and Cocke 1984).

In the 110 cases in which each community is located at least 100 air miles from any other hub airport, 29 of the communities lost all scheduled air service. In regard to the remaining 81 communities, 49 have endured service cuts (i.e., fewer seats available per week) while 32 are experiencing service improvements. Insofar as the aforementioned fear is concerned, i.e., a reduction or elimination of service will cause the population of the city or town to spiral downward, the apprehension seems unfounded. That is not to say that some cities and towns did not experience a population loss. However, twentyone of those 29 confronted the cessation of service and obviously found ways to compensate for the loss of one degree of freedom, i.e., one less transportation option.

Probably a more startling and possibly more confounding finding evolving out of this study, is the fact that those cities and towns that have had a continuation of some level of service experienced a nearly identical pattern of population growth as did those that lost all service. This paradox clearly suggests that more research is needed to understand the numerous other variables, demographic, economic and geographic, and how they relate to one another in effecting change in small communities. 


\section{REFERENCES}

Addus, Abdussalam (1985), "Subsidizing Air Service to Small Communities," Transportation Quarterly, 39 (October), 537-552.

(1984), "Essential Air Service Determination for Small Communities," Transportation Quarterly, 38 (October), 559-574.

Civil Aeronautics Board (1981), Report on Airline Service, Fares, Traffic, Load Factors, and Market Shares, Washington, D.C., November.

Cunningham, Lawrence $F$. and E. Woodrow Eckard (1987), "U.S. Small Community Air Service Subsidies," Journal of Transport Economics and Policy, September, 255277.

Davis, Grant M. and John E. Dillard Jr. (1982), "The Professional Traveler and the Airline Deregulation Act of 1978: An Appraisal," Proceedings of the Transportation Research Forum, XXIII, Number 1, 419-426.

Gallagher, John E. (1990), "Where There's No Bus, There's No Exit," Time, March 26, 59.

Greyhound Lines, Inc. (1998), "Greyhound Ticket Sales Increase 11.5 Percent in September; Third Quarter sales Rose 5 Percent Over 1997," PR Newsuire, October 8, <http:// biz.yahoo.com/prnews >

Jones, J. Richard and Sheila I. Cocke (1981), "A Performance Evaluation of Commuter Airlines: The Passenger's View," Proceedings of the Transportation Research Forum, XXII.
(1984), "The Subsidy Factor in Airline Service to Small Communities: An Analysis of Section 419," Southern Marketing Association Proceedings.

(1985), "An Analysis of Commuter Airline Service in Western Markets Subsequent to Deregulation," Proceedings of American Institute for Decision Sciences, Western Region, 252254.

Kihl, Mary (1988), "The Impacts of Deregulation on Passenger Transportation in Small Towns," Transportation Quarterly, 42 (April), 243-268.

Meyer, James S (1981), "Section 419 of the Airline Deregulation Act: What Has Been The effect On Air Service To Small Communities," Jonumal of Air Law and Commerce, 47 (Fall), 151-185.

Meyer, John R., Clinton V. Oster, Ivor P. Morgan, Benjamin A. Berman, and Diana L.

Strassman (1981), dirline Deregulation, The Early Experience, Boston: Auburn House Publishing Co.

Regional Airline Association (1998), The 1998 Anmual Report of the Regional Airline Association.

Reich, Robert B. (1987), "The Rural Crisis and What to Do About It," NRECA Management Quarterly, Winter, 34-39.

Schwab, Jim (1987), "You Can't Get There From Here," Plaming, July, 26-29.

Shultz, Paul (1987), "In the Gateway of Commerce: The Impact of Deregulation on Rural Transportation Services," Rural Telecommunications, Fall, 28-30. 
Stephenson, Frederick J. and Frederick J. Beier (1981), "The Effects of Airline Deregulation on Air Service to Small Communities," Transportation Journal, Summer, 54-62.

U.S. Department of 'Transportation (1997), Transportation Statistics Annual Report 19.97

U.S. Senate, Committee on Commerce, Science, and Transportation (1996), Domestic Air services in the Wake of Airline Deregulation: Challenges Faced by Small Curriers.
Vellenga, David B. and Daniel R. Vellenga (1986), "Essential Airline Service Since Deregulation: Selected states in the Northwestern and Southwestern U. S.," Logistics and Transportation Review, 22 (December), 339-370.

Williamson, Kenneth C., Lawrence F. Cunningham and Marc G. Singer (1982), "Scheduled Passenger Air Service To Small Communities: A Role For State And Local Governments," Transportation Journal, Summer, 25-34.

\section{AUTHOR BIOGRAPHY}

J. Richard Jones is the George R. Brown Distinguished Professor of Business at Trinity University, San Antonio, Texas. Prior to his present position, he was Distinguished Professor of Transportation at Memphis State University. In addition, Dr. Jones has been on the faculties of The University of Georgia and the University of Houston. He also spent four year's in the Office of the Secretary of Transportation, Washington, DC. Dr. Jones received his PhD from Arizona State University and his MBA and BA from Michigan State University. 